favourably placed either geographically or historically for independent developments in science. The relatively small population of the country, the great population changes of the 1940s (leading to a considerable rise in the proportion of Russians and other nonEstonians in the population), the proximity of the great scientific centres of Leningrad, the difficulties imposed by the little-known nature of the Estonian language (implying that the bulk of scientific publication will now be in Russian, as it was formerly in German)-all would seem to tend to the development of science in Estonia as part of Soviet science generally, and with no specific features of its own.

Yet this is not so. Although, of course, scientific projects in the Estonian SSR must be integrated into the planning of the union as a whole, yet within the overall framework, Estonian scientists have established some special fields of study. Interviewed in connexion with the Lenin Days of Science, the president of the Estonian Academy of Science, A. Veimer, outlined the work being done by the academy in a number of diverse fields including the utilization of fuel-bearing shales (the most important natural resource of Estonia), the technology of exploiting and processing these shales and research into the properties of their fuel products; rescarch into biologically active substances and their synthesis, notably the work of K. Lyaets, of the Institute of Chemistry of the Estonian Academy of Sciences, on the obtaining of vitamins A, E and $\mathrm{K}$ and also citral (used in perfumery) from petroleum; solid state research, under the direction of F. Klement of the University of Tartu, specializing in luminescence; the production of a geological and ecological map of the republic, and research into the scientific use of Fistonia's natural resources. The principal scientific body of the republic is the Academy of Sciences, which at present comprises eleven scientific institutes and other smaller units. In all, some 2,500 scientists are working within the framework of the academy.

During the Lenin Days of Science, tribute was paid to Estonian, research generally by the presentation to the Estonian delegation of the gold medal of the "Exhibition of Achievements of the National Economy of the USSR", awarded, in this case, for "achievements in various branches of scicnce".

\section{NATURE RESERVES}

\section{More Countryside Protected}

DURING the past thrce weeks, the Nature Conservancy has announced one new national nature reserve and four extensions to existing reserves. This photograph shows part of the Oxwich Bay National Nature Reserve on the south coast of the Gower Peninsula in Glamorgan. The bulk of the reserve was established in 1963 , but a further 22 acres has been purchased from the Forestry Commission, bringing the total to 564 acres. The new area consists of a limestone cliff on which many interesting plants grow, and a small woodland with well developed sessile oak, ash, elm and lime, and with several specimens of a rare type of whitebeam. Other extensions include an area of 2,093 acres on the Durham side of Teesdale between. High Force and Cow Green which has been added to the Upper Teesdale nature reserve. The new section includes Widdybank Fell, which is a famous botanical

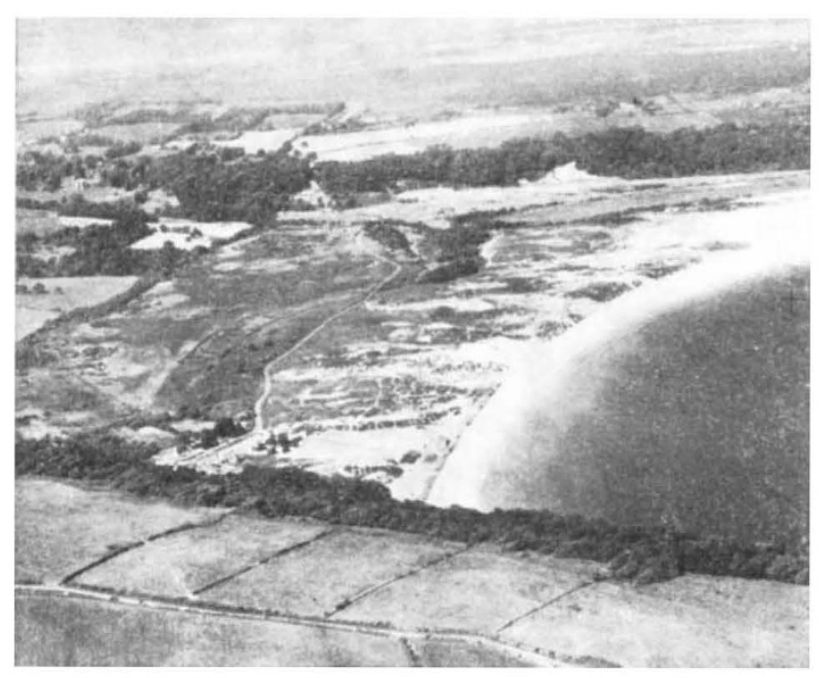

Oxwich Bay National Nature Reserve, Gower Peninsula, Glamorgan. Oblique aerial photograph looking north-eastwards over the sand dunes of the reserve across the Gower to the Burry Inlet beyond.

locality, and also meadows, pastures and relict woodland. The new reserve is in Anglesey, about 4 miles north of Llangefni. It has been established by lease to protect an interesting fen which is permeated by water draining from a limestone escarpment. The fen contains several rare and local plants and has developed from a lake which existed after the last Ice Age about 10,000 years ago.

\section{HOSPITALS}

\section{Survival of the Unfit}

ALL over Britain, mistakes in hospital design are being perpetuated, according to a report from the King Edward's Hospital Fund for London, because there has been little systematic study in the past of how new hospital buildings are actually used (Evaluating New Hospital Buildings, $23 s 6 d$ ). The few evaluations of hospital buildings that have becn carried out reveal that in most modern hospitals the buildings are either too hot or too cold; they are also often noisy at night and the lighting is often either too bright or too dark. But the designers are not always to blame, the report says, because previous studies also reveal the misuso of carefully designed facilities. "In only one case," the report says, "was the building and equipment being used in exactly the way predicted by the skilled team which planned and designed it."

The authors of the report, Mr Ken Baynes, Mr Brian Langslow and Dr Courtenay Wade, say that the present situation, with its resulting serious inconveniences and waste, cannot be resolved simply by finding another architect or even spending more money.

The authors of this report discuss the future of evaluation studies of new hospitals and critically review those so far carried out. They ask that evaluation studies should not originate from some central organization but from teams of planners, designers and managers responsible to the regional hospital boards. They also ask for a central coordinating body to interpret and encourage the studies. 